\title{
UNJUK KERJA TURBIN ANGIN TIPE POROS HORIZONTAL 3 SUDU BERDIAMETER 2,4 METER
}

\author{
Sapto Prayogo ${ }^{1}$, Memey Meida Sari ${ }^{2}$ \\ Teknik Konversi Energi Politeknik Negeri Bandung \\ Email: saptoprajogo@yahoo.com
}

\begin{abstract}
Abstrak
Indonesia merupakan negara kepulauan yang memiliki potensi sumber energi angin cukup tinggi. Pembuatan dan instalasi turbin angin di Indonesia masih belum berkembang pesat, dan penggunaannya masih pada jenis angin berkategori baik $(>5 \mathrm{~m} / \mathrm{s})$. Pada penelitian ini dilakukan unjuk kerja turbin angin tipe poros horisontal 3 sudu dengan diameter 2,4 meter pada jenis angin marginal (kecepatan angin 3-4 m/s). Bahan yang digunakan untuk pembuatan sudu turbin adalah komposit. Berdasarkan hasil pengujian diperoleh efisiensi tertinggi pada saat pengujian tanpa beban sebesar 4,60\% pada kecepatan angin 3,5 m/s dengan putaran $95,5 \mathrm{rpm}$, sedangkan pengujian saat berbeban sebesar 3,64\% pada kecepatan angin $3,2 \mathrm{~m} / \mathrm{s}$ dengan putaran $66,50 \mathrm{rpm}$.
\end{abstract}

Kata kunci : Efisiensi, Diameter, Torsi, Putaran, Potensi Angin Marginal

\begin{abstract}
Indonesia is an archipelago country that has potential of wind energy resources. Manufacturing and installation of wind turbines in Indonesia are still growing, and its usage is still on the type of good categorized winds $(>5 \mathrm{~m} / \mathrm{s})$. In this study the performance of horizontal axis wind turbines of type 3 blades with a diameter of 2,4 meters on the type of marginal wind (wind speed of 3-4 m/s). The materials used for the manufacture of turbine blades is a composite. Test results obtained the highest efficiency without load was $4.60 \%$ at $3.5 \mathrm{~m} / \mathrm{s}$ of wind speed with $95,5 \mathrm{rpm}$ of rotation, while loadedtest obtained $3,64 \%$ efficiency at $3.2 \mathrm{~m} / \mathrm{s}$ of a wind speed, and $66,5 \mathrm{rpm}$ of rotation.
\end{abstract}

Keywords: Efficiency, Diameter, Torque, Rotary speed, Marginal Wind Potency

\section{PENDAHULUAN}

Kebijakan energi di Indonesia yang telah mengarah kepada pemanfaatan sumber energi baru-terbarukan (EBT) , merupakan kesempatan besar bagi pengembangan dan implementasi teknologi konversi energi berbasis sumber energi terbarukan. Target penggunaan sumber energi terbarukan khususnya angkin, hidro, surya dan EBT lainnya mencapai porsi $17 \%$ pada tahun 2025 , dimana nilai tersebut meningkat 3 kali lipat dari porsi di tahun 2012 (ESDM, 2012). Salah satu sumber energi terbarukan yang potensial di Indonesia adalah energi angin. Letak geografis Indonesia yang merupakan kepulauan, memiliki kapasitas total energi angin mencapai 9,29 GW dan total kapasitas terpasang untuk pembangkit listrik tenaga angin, baru mencapai 1,6 MW (Martosaputro dan Murti, 2014). Berdasarkan data yang diperoleh LAPAN, kategori potensi angin berdasarkan kecepatan angina pada $50 \mathrm{~m}$ di Indoensia dibagi menjadi 3, yaitu marginal (3$4 \mathrm{~m} / \mathrm{s})$, sedang $(4-5 \mathrm{~m} / \mathrm{s})$, dan baik $(>5 \mathrm{~m} / \mathrm{s})$. Penggunaan turbin angina yang banyak diinstalasi di Indonesia adalah turbin angina tipe horizontal dengan pemasangan yang dilakukan pada tempat dengan sumber angina sedang dan baik. Turbin angina horizontal adalah turbin angin dengan sumbu horizontal yang memiliki sudu yang berputar dalam bidang vertical dimana aliran udara pada salah satu sisinya dapat bergerak lebih cepat dari aliran udara di sisi yang lain ketika angin melewatinya. Fenomena ini menimbulkan daerah tekanan 
rendah pada belakang sudu dan daerah tekanan tinggi di depan sudu. Perbedaan tekanan ini membentuk gaya yang menyebabkan sudu berputar (Daryanto, Y. 2007)

Energi angin adalah energi yang terkandung pada massa udara yang bergerak. Energi angin berasal dari energi matahari. Pemanasan bumi oleh sinar matahari menyebabkan perbedaan massa jenis $(\rho)$ tekanan pada udara sehingga akan terjadi aliran fluida dan menghasilkan angin. Energi angin dapat dimanfaatkan dengan menggunakan alat pengkonversi energi angin berupa turbin angin, dimana prinsip kerjanya adalah energi kinetik angin diubah menjadi energi mekanik berupa putaran poros turbin, kemudian energi mekanik ini diubah menjadi energi listrik dengan menggunakan generator. Pada penelitian Frimadi (2011), dilakukan pembuatan dan pengujian turbin angin sumbu horizontal 3 sudu dengan diameter 2,4 meter tipe down wind dengan jenis angin berkecepatan rendah hingga baik $(11 \mathrm{~m} / \mathrm{s})$.

Sebagai upaya mengetahui performansi turbin angin poros horizontal 3 sudu dengan tipe angina marginal (kecepatan rendah), maka dilakukan penelitian yang menggunakan pendekatan kuantitatif, dimana sebagian besar data belum ada diakuisisi secara langsung melalui eksperimen pada alat turbin angin tipe horizontal 3 sudu berdiameter 2,4 meter.

\section{METODOLOGI}

Penelitian turbin angin poros horizontal dilakukan dalam beberapa tahap, yaitu diawali dengan studi literatur terkait pemanfaatan energi angin untuk turbin angin, tahap perhitungan ukuran diameter sudu turbin angin, dan pembuatan komponen-komponen turbin angin berupa sudu, $h u b$, ekor dan tower. Kemudian dilakukan perakitan turbin angin, dan langkah terakhir adalah pengujian turbin angin.

Perhitungan ukuran diameter sudu turbin angin menggunakan persamaan (1).

$D=\sqrt{\frac{P}{C p \cdot \frac{\rho}{2} \cdot \frac{\pi}{4} \cdot v^{3}}}$

Dimana $\mathrm{P}$ adalah daya poros yang diinginkan dalam satuan Watt, $\rho$ adalah masa jenis udara dalam satuan $\left(\mathrm{kg} / \mathrm{m}^{3}\right), \mathrm{Cp}$ adalah Coefficient Of Performance, dan v adalah kecepatan angin dalam satuan $\mathrm{m} / \mathrm{s}$.

Komponen untuk turbin angin yang dibuat adalah sebagai berikut. Sudu turbin angin dibuat dari bahan komposit, yang dibentuk melalui proses pencetakan, dan dilapisi dengan gel coat, fiberglass dan resin. Adapun hub, tower dan ekor turbin angin, dibuat dari material besi dengan tebal $2 \mathrm{~mm}$ untuk hub, besi dengan tebal $1 \mathrm{~mm}$ untuk ekor dan besi siku untuk tower.

Turbin angin yang telah selesai dirakit, selanjutnya diuji performansi. Uji performansi dilakukan sebanyak dua jenis, yaitu berupa pengujian tanpa beban dan pengujian dengan beban, dimana beban pada pengujian performansi turbin angin berupa generator.

Parameter uji performansi turbin angin meliputi kecepatan angin (v), putaran poros turbin (n) dan torsi (Nm). Akuisisi data dilakukan menggunakan alat anemometer untuk mengukur kecepatan angin, tachometer untuk mengukur putaran poros dan neraca untuk mengukur torsi.

\section{HASIL DAN PEMBAHASAN}

Data pengujian tanpa beban dan berbeban dilakukan sebanyak enam kali. Data pengujian tanpa beban disajikan pada Tabel 1 . Pengambilan data dilakukan pada saat kecepatan angin $3 \mathrm{~m} / \mathrm{s}$ hingga $4,6 \mathrm{~m} / \mathrm{s}$. Sedangkan pengujian berbeban dapat dilihat pada Tabel 2. Pengambilan data dilakukan pada saat kecepatan angin $3,1 \mathrm{~m} / \mathrm{s}$ hingga 5,1 $\mathrm{m} / \mathrm{s}$.

Tabel 1. Pengujian Tanpa Beban

\begin{tabular}{|c|c|c|c|c|c|c|}
\hline \multirow{2}{*}{ No. } & $\begin{array}{c}\text { Kecepatan } \\
\text { Angin }\end{array}$ & $\begin{array}{c}\text { Temperatur } \\
\text { Lingkungan }\end{array}$ & Putaran & $\begin{array}{c}\text { Massa } \\
1\end{array}$ & Massa 2 & Torsi \\
\cline { 2 - 7 } & $(\mathrm{m} / \mathrm{s})$ & $\left({ }^{\circ} \mathrm{C}\right)$ & $(\mathrm{rpm})$ & $(\mathrm{kg})$ & $(\mathrm{kg})$ & $(\mathrm{Nm})$ \\
\hline 1 & 3,0 & 27 & 83,50 & 2 & 5,1 & 0,30 \\
2 & 3,3 & 27,5 & 89 & 2 & 6,7 & 0,46 \\
3 & 3,5 & 27,5 & 95,5 & 2 & 7,3 & 0,52 \\
4 & 3,9 & 27,2 & 102,5 & 2 & 7,8 & 0,57 \\
5 & 4,2 & 27,1 & 112 & 2 & 8,3 & 0,62 \\
6 & 4,6 & 27 & 120 & 2 & 8,9 & 0,68 \\
\hline
\end{tabular}


Tabel 2. Pengujian Berbeban

\begin{tabular}{|c|c|c|c|c|c|c|}
\hline \multirow{2}{*}{ No. } & $\begin{array}{c}\text { Kecepatan } \\
\text { Angin }\end{array}$ & $\begin{array}{c}\text { Temperatur } \\
\text { Lingkungan }\end{array}$ & Putaran & $\begin{array}{l}\text { Massa } \\
1\end{array}$ & Massa 2 & Torsi \\
\cline { 2 - 7 } & $(\mathrm{m} / \mathrm{s})$ & $\left({ }^{\circ} \mathrm{C}\right)$ & $(\mathrm{rpm})$ & $(\mathrm{kg})$ & $(\mathrm{kg})$ & $(\mathrm{Nm})$ \\
\hline 1 & 3,1 & 26,8 & 63 & 2 & 4,8 & 0,27 \\
2 & 3,2 & 27,2 & 66,50 & 2 & 6,6 & 0,45 \\
3 & 3,7 & 27,2 & 80 & 2 & 7,2 & 0,51 \\
4 & 4,3 & 27,2 & 88 & 2 & 7,8 & 0,57 \\
5 & 4,5 & 26,7 & 92 & 2 & 8,2 & 0,61 \\
6 & 5,1 & 26,7 & 101 & 2 & 8,7 & 0,66 \\
\hline
\end{tabular}

Hasil pengolahan data yang telah diakuisisi diplotkan ke dalam bentuk grafik yang dapat dilihat pada Gambar 1 hingga Gambar 6.

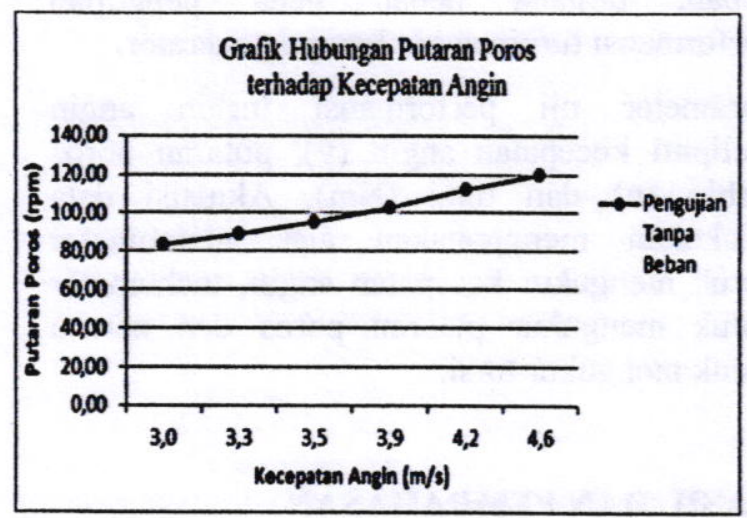

Gambar 1. Hubungan Putaran Poros terhadap Kecepatan Angin tanpa beban

Dari Gambar 1 dapat dilihat bahwa pada pengujian tanpa beban, putaran poros semakin meningkat seiring dengan bertambahnya kecepatan angin. Kecepatan angin sangat berpengaruh terhadap putaran, karena kecepatan angin yang semakin besar akan mampu menggerakan sudu turbin relatif cepat, sehingga ketika sudu turbin berputar, maka putaran poros yang dihasilkan akan menjadi besar juga.

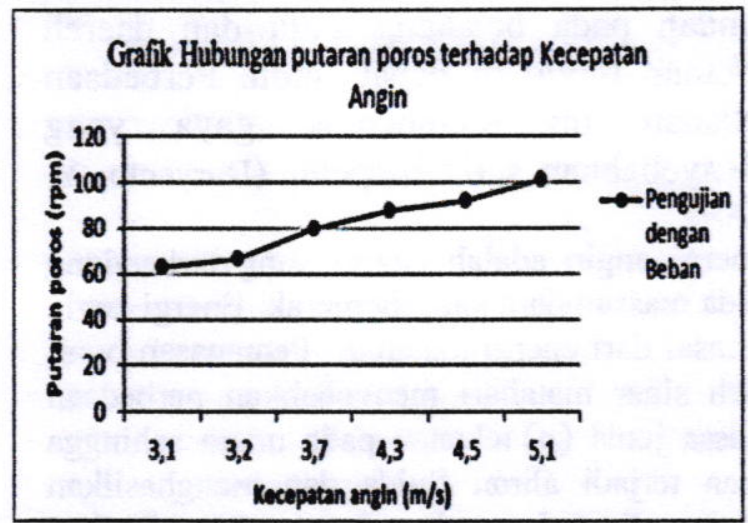

Gambar 2. Hubungan Putaran Poros terhadap Kecepatan Angin berbeban

Pada pengujian berbeban dengan menggunakan generator (Gambar 2) pada dasarnya sama seperti pengujian tidak berbeban, artinya putaran poros semakin meningkat seiring dengan bertambahnya kecepatan angin. Pada kecepatan angin $5,1 \mathrm{~m} / \mathrm{s}$ putaran poros yang dihasilkan sekitar $101 \mathrm{rpm}$.

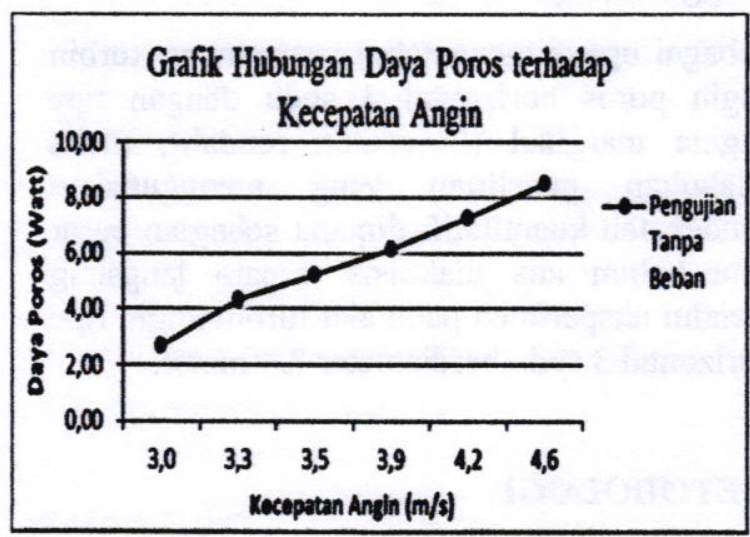

Gambar 3 Hubungan Daya Poros terhadap Kecepatan Angin tanpa beban

Dari Gambar 3 dapat dilihat bahwa pada pengujian tanpa beban, daya poros semakin meningkat seiring dengan bertambahnya kecepatan angin. Nilai daya poros tertinggi saat tidak dibebani sebesar 8,50 Watt pada saat kecepatan angin $4,6 \mathrm{~m} / \mathrm{s}$. 


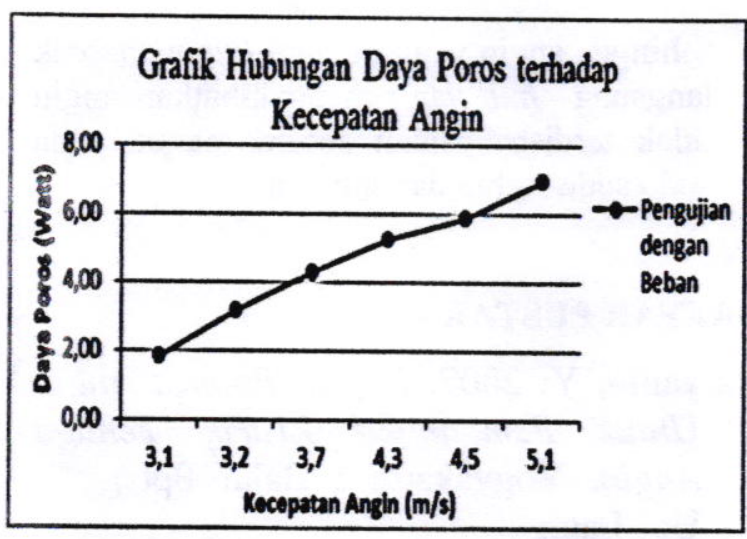

Gambar 4 Hubungan Daya Poros terhadap Kecepatan Angin berbeban

Karakterisitk pengujian berbeban (Gambar 4) pada dasarnya sama seperti pengujian tidak berbeban, artinya daya poros semakin meningkat seiring dengan bertambahnya putaran poros. Daya poros terbesar saat dibebani sebesar 6,96 Watt pada saat putaran poros $5,1 \mathrm{~m} / \mathrm{s}$.

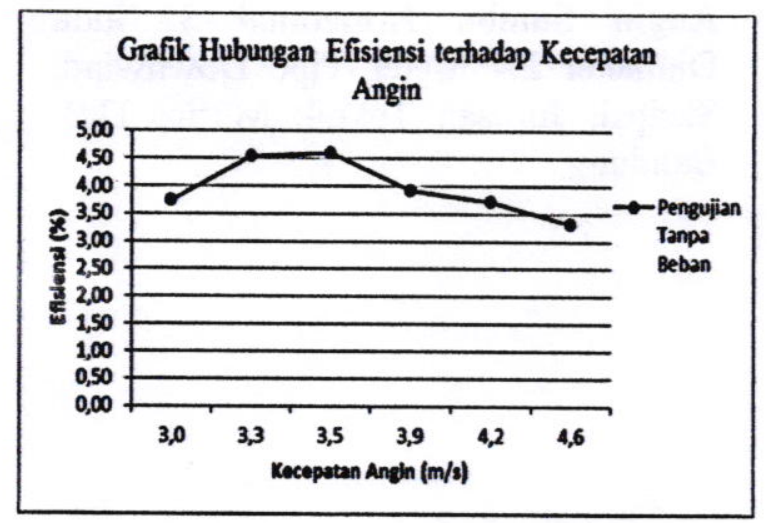

Gambar 5 Hubungan Efisiensi terhadap Kecepatan Angin tanpa beban

Dari Gambar 5 dapat dilihat bahwa pada pengujian tanpa beban, efisiensi dipengaruhi oleh kecepatan angin. Efisiensi naik pada saat kecepatan 3,3 - 3,5 m/s, namun kembali turun pada kecepatan angin $3,9 \mathrm{~m} / \mathrm{s}$. Efisiensi optimum saat tidak dibebani sebesar $4,60 \%$ pada kecepatan $3,5 \mathrm{~m} / \mathrm{s}$.

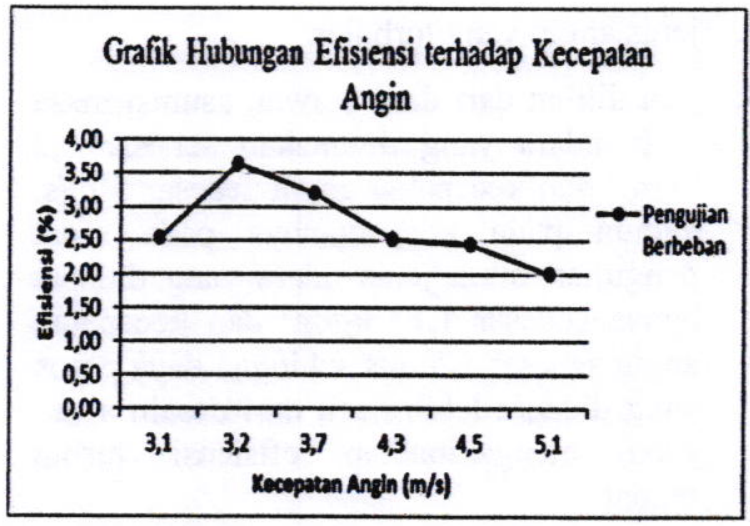

Gambar 6 Hubungan Efisiensi terhadap Kecepatan Angin berbeban

Pada pengujian berbeban (Gambar 6), efisiensi naik pada saat kecepatan $3,2 \mathrm{~m} / \mathrm{s}$, namun kembali turun pada kecepatan angin $3,7 \mathrm{~m} / \mathrm{s}$. Efisiensi optimum saat dibebani adalah sebesar 3,64 \% pada kecepatan 3,2 m/s.

Kecepatan angin sangat berpengaruh terhadap efisiensi turbin, dimana efisiensi turbin ini didapat dari perbandingan antara daya poros yang dihasilkan turbin dengan daya input angin yang dihasilkan. Daya input angin dan daya poros ini didapat melalui persamaan, dimana salah satu parameter yang diperlukan dalam perhitungan tersebut adalah kecepatan angin.

Daya poros juga dipengaruhi oleh besarnya kecepatan putaran poros dengan besarnya torsi. Semakin besar putaran dan torsi maka daya poros yang dihasilkan semakin besar juga. Sedangkan daya input angin berbanding lurus dengan kecepatan angin.

Efisiensi tertinggi yang didapat pada pengujian tanpa beban sebesar $4,60 \%$ sedangkan dengan beban sebesar 3,64 \%. Sedangkan daya poros tertinggi yang dihasilkan tanpa beban sebesar 8,50 Watt dan pengujian dengan beban sebesar 6,96 Watt. Hal tersebut jauh dari perhitungan secara teoritis. [secara teoretis berapa?]

Hal tersebut diakibatkan karena beberapa hal diantaranya yaitu :

1. hub yang dibuat terbuat dari plat besi dengan tebal $2 \mathrm{~mm}$, sehingga angin yang melalui hub menabrak langsung hub yang mengakibatkan angin tidak terdistribusikan secara merata pada sudu sudu turbin. 
2. jenis angin yang turbulen

3. jika dilihat dari desain awal, asumsi masa jenis udara yang digunakan sebesar 1,2 $\mathrm{kg} / \mathrm{m}^{3}$ dan kecepatan angin sebesar $5 \mathrm{~m} / \mathrm{s}$, namun pada kenyataannya pada saaat pengujian masa jenis udara yang didapat hanya sebesar $1,17 \mathrm{~kg} / \mathrm{m}^{3}$ dan kecepatan angin sebesar $3,5 \mathrm{~m} / \mathrm{s}$ sehingga daya poros yang didapat lebih kecil dari desain awal, yang mengakibatkan efisiensi turbin rendah.

\section{KESIMPULAN}

Berdasarkan data dan hasil perhitungan yang diperoleh, maka dapat ditarik kesimpulan diantaranya yaitu :

1. Turbin angin yang dibuat mampu menghasilkan daya poros sebesar 8,50 Watt (pengujian tanpa beban) dan 6,96 Watt (pengujian dengan beban).

2. Efisiensi tertinggi saat pengujian tanpa beban sebesar $4,60 \%$ sedangkan pengujian saat berbeban sebesar 3,64\%.

3. Efisiensi dan daya poros yang didapat dari hasil pengujian jauh dari perhitungan secara teoritis, hal tersebut diakibatkan karena jenis angin yang turbulen, material $h u b$ yang digunakan terbuat dari besi sehingga angin yang melalui hub menabrak langsung $h u b$ yang mengakibatkan angin tidak terdistribusikan secara merata pada sudu sudu turbin dan lainnya.

\section{DAFTAR PUSTAKA}

Daryanto, Y. 2007. Kajian Potensi Angin Untuk Pembangkit Listrik Tenaga Angin. Yogyakarta : Balai Pptagg Upt-Lagg

Esdm, 2012, Program Of Bioenergy Development In Indonesia, Energy And Environment Partnership (Eep) Indonesia Annual Forum, Pekanbaru Riau.

Martosaputro, S. Dan Murti, N., 2014. Blowing The Wind Energi In Indonesia. Energy Procedia, 273-282.

Frimadi Hilman, 2011. Perancangan, Pembuatan Dan Pengujian Turbin Angin Sumbu Horizontal 3 Sudu Diameter 2,4 Meter Tipe Downwind, Skripsi, Jurusan Teknik Mesin, ITB. Bandung 